\title{
COINS FROM MINTS OF THRACE AND LOWER MOESIA ON THE VIMINACIUM CEMETERY "VIŠE GROBALJA"
}

\begin{abstract}
Coin finds from mints of Thrace and Lower Moesia dating from 2nd and 3rd century that were discovered on the Viminacium necropolis "Više Grobalja" are of great importance for tracing the ways of monetary circulation in the Balkan and Danubian provinces of the Empire. At this necropolis, 25 examples were discovered, dating from the time of Antoninus Pius to Philipp I.
\end{abstract}

\section{Key words: Roman provincial minting, Thrace, Lower Moesia, Viminacium.}

During the systematic archaeological excavation of the Viminacium necropolis "Više Grobalja", 25 examples of bronze coins were found, minted either in Thrace or Lower Moesia (Table 1). ${ }^{1}$ Studying of numismatic finds from the cemeteries of Viminacium offers possibilities for new and exceptional discoveries, mostly because of the fact that one comes upon a huge sample from reliable archaeological contexts. Final publication of the whole numismatic fundus from this ancient

1 Systematic excavations of the southern Viminacium cemetery (sites „Više Grobalja“ and „Pećine“) were undertaken from 1978 to 1987. Coins found at the site „Više Grobalja" were published so far, making some $40 \%$ of all the numismatic finds from the southern Viminacium cemetery. site will represent a great contribution to the study of Roman coinage and point out once more the great importance Viminacium once had, as an important administrative, economic and military metropolis in this part of the Empire.

\begin{tabular}{|c|c|c|}
\hline Thrace & & \\
\hline & Hadrianopolis & 3 \\
\hline & Augusta Traiana & 1 \\
\hline & Mesembria & 1 \\
\hline & Pautalia & 9 \\
\hline & Perinthos & 2 \\
\hline & Plotinopolis & 1 \\
\hline & Philippopolis & 2 \\
\hline
\end{tabular}

* The article results from the project: Viminacium, Roman city and military legion camp - research of material and non material of inhabitants by using the modern technologies of remote detection, geophysics, GIS, digitalisation and $3 D$ visualisation (no 47018), funded by Ministry of Education and Science of the Republic of Serbia. 


\begin{tabular}{|c|c|c|}
\hline $\begin{array}{c}\text { Lower } \\
\text { Moesia }\end{array}$ & Marcianopolis & 1 \\
\hline & Nicopolis ad Istrum & 5 \\
\hline & & 25 \\
\hline Total &
\end{tabular}

Table 1. Coins from the mints of Trace and Lower Moesia from the necropolis "Više Grobalja".

It is especially interesting to track down the ways of circulation in the Balkan provinces of the Roman Empire and that is why our intention was drown by the Thracian and Moesian examples found at Viminacium. As already known, the difference between provincial and imperial coinage is in their areas of circulation. On the other hand, during the first half of 3rd century, one felt the lack of small bronze coins within the Balcan provinces (Borić-Brešković 1976: 8, ref. 2). It is therefore obvious that coins from the local Balcan were replacing bronze coins from the Roman mint on a large scale. ${ }^{2}$ The coins from Thracian and Moesian mints found at the neropolis „Više Grobalja“ can be dated from the period of Antoninus Pius to Philipp I (Table 2).

2 Apart from coins from the mentioned mints of Viminacium, Thrace and Lower Moesia, at the „Više Grobalja" necropolis there are also coins from other Balkan mints: Stobi, Philippoi, Union of Macedonian cities and coins from the province of Dacia.
It is noticeable that coins from these mints circulated towards the West already in the second half of 2nd century, being most intense during Severian times and then starting to decline, which corresponds with opening of the Viminacium mint, which began to mint enough bronze coins at the territory of Upper Moesia. An almost identical picture of circulation and chronology is shown related to the coins of the Nicaea mint, much represented at the „Više Grobalja“ necropolis (Vojvoda 2011: 243-256). Geographical position of Viminacium, at the cross-road of many roads, of which the main lead towards the south to Naissus and after that over Thrace and Bosphorus, made it one of the most important points on the road towards the East. Wars, that often broke out starting from the time of Septimius Severus and becoming even more numerous during his heirs, lead to a great circulation of people, goods and money along the road over Thrace and Upper Moesia. Obviously, there were several reasons that lead to a greater money circulation between the Balkan provinces and the provinces in Asia Minor, especially from Bithynia, over Thrace and Upper Moesia and ever further to the West, since at the same time finds of Nicaean coins were found at the territory of the southeast Alps (Kos 1986: 107-109). ${ }^{3}$

3 Emona - Iulia Maesa (1 pc.) i Severus Alexander

\begin{tabular}{|c|c|c|}
\hline Emperor or a family member & no. of pieces & $\%$ \\
\hline Antoninus Pius & 2 & 8 \\
\hline Marcus Aurelius & 2 & 12 \\
\hline Faustina Iunior & 3 & 4 \\
\hline Commodus & 1 & 16 \\
\hline Septimius Severus & 4 & 20 \\
\hline Caracalla & 5 & 4 \\
\hline Plautilla & 1 & 12 \\
\hline Geta & 3 & 4 \\
\hline Elagabalus & 1 & 8 \\
\hline Gordian III & 2 & 4 \\
\hline Philipp Senior & 1 & 100 \\
\hline Total & 25 &
\end{tabular}

Table 2. Coin percentage of different emperors and their family members. 
Further research and publishing the greatest numbe possible of all the coins from Upper Moesia, as well as from Thrace and Lower Moesia will make it possible for us to understand historical circumstances and consequences they had on life in these neighbouring provinces.

(1); Poetovio - Elagabalus (2), Severus Alexander (3), Iulia Mammaea (1). 


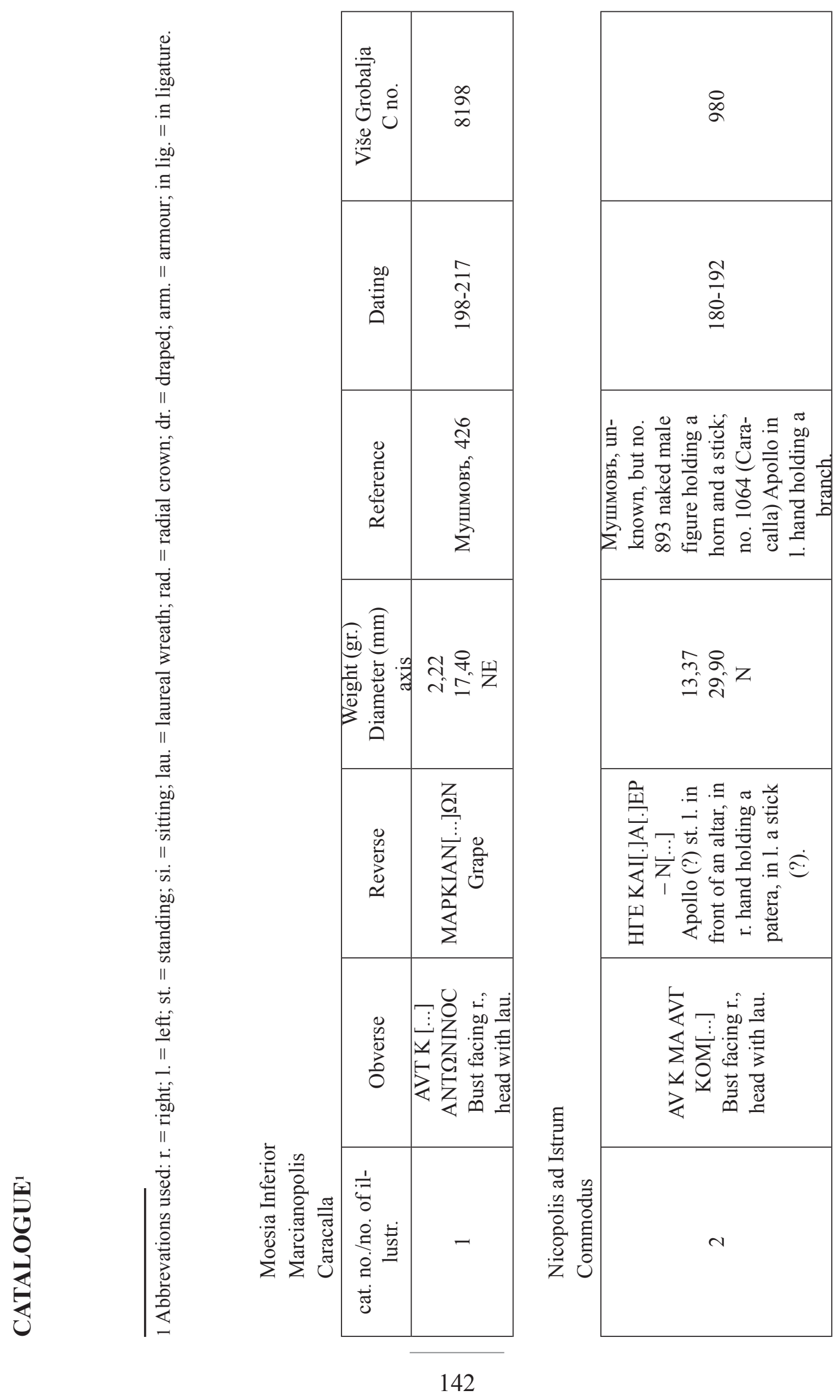




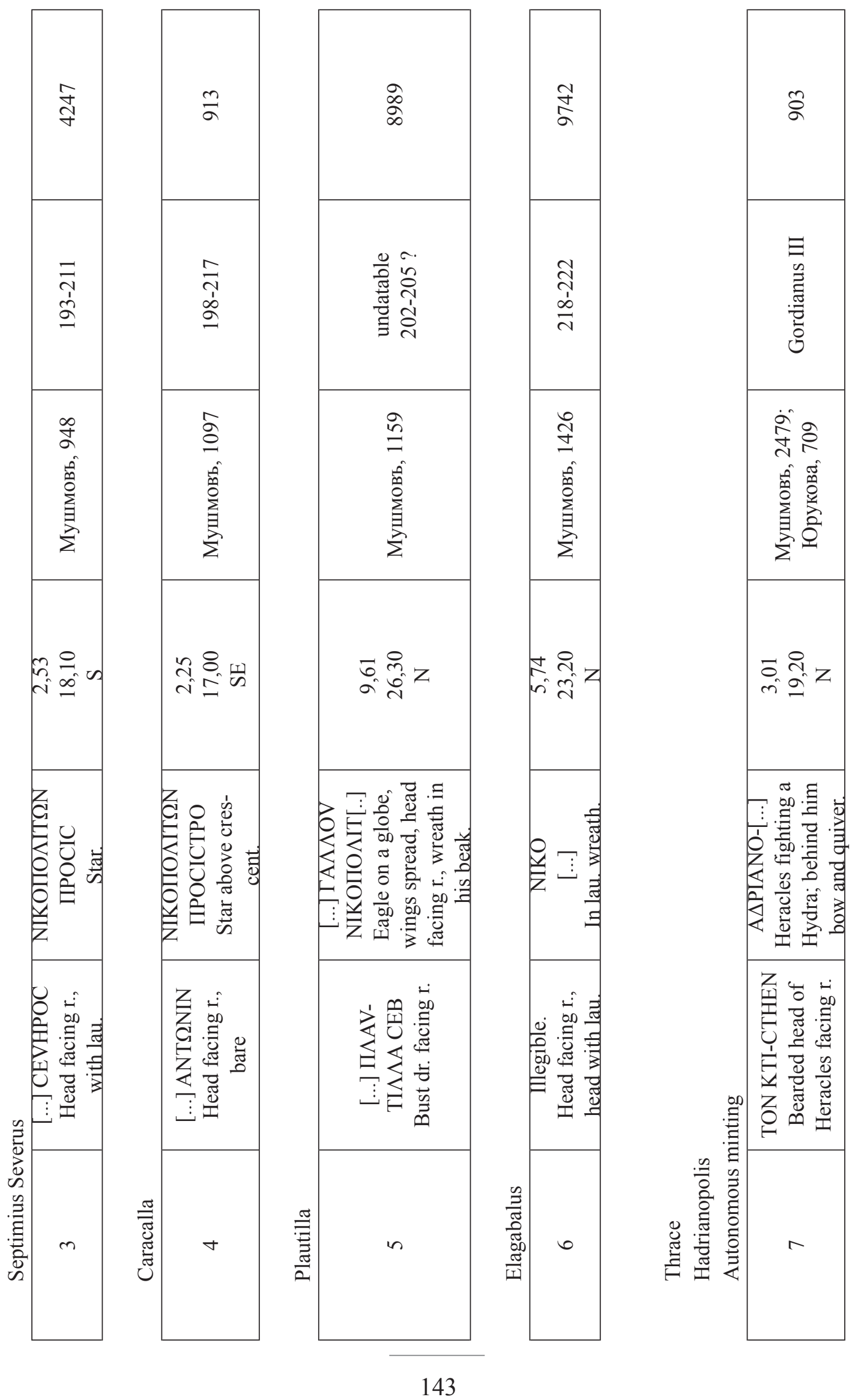



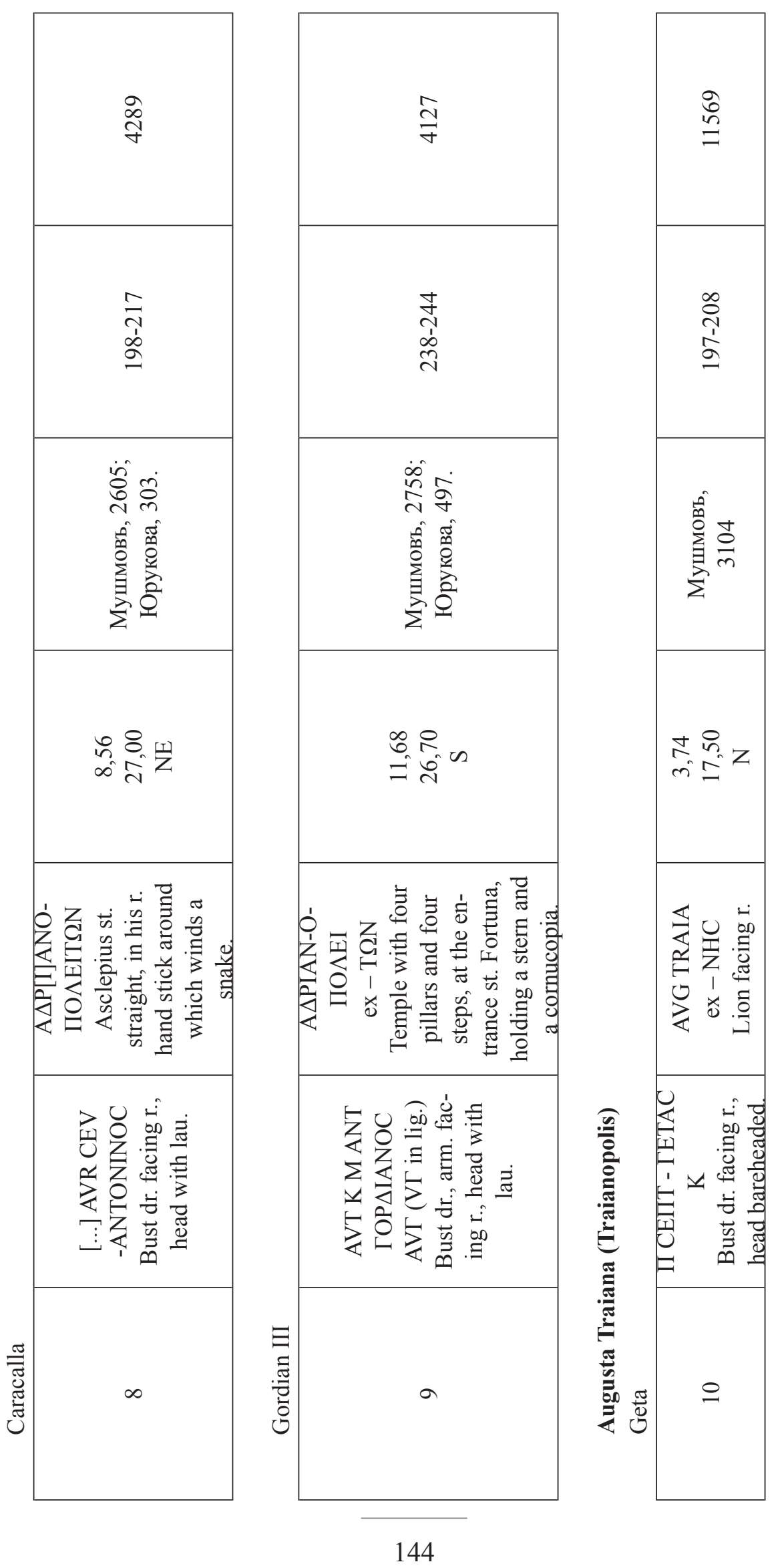

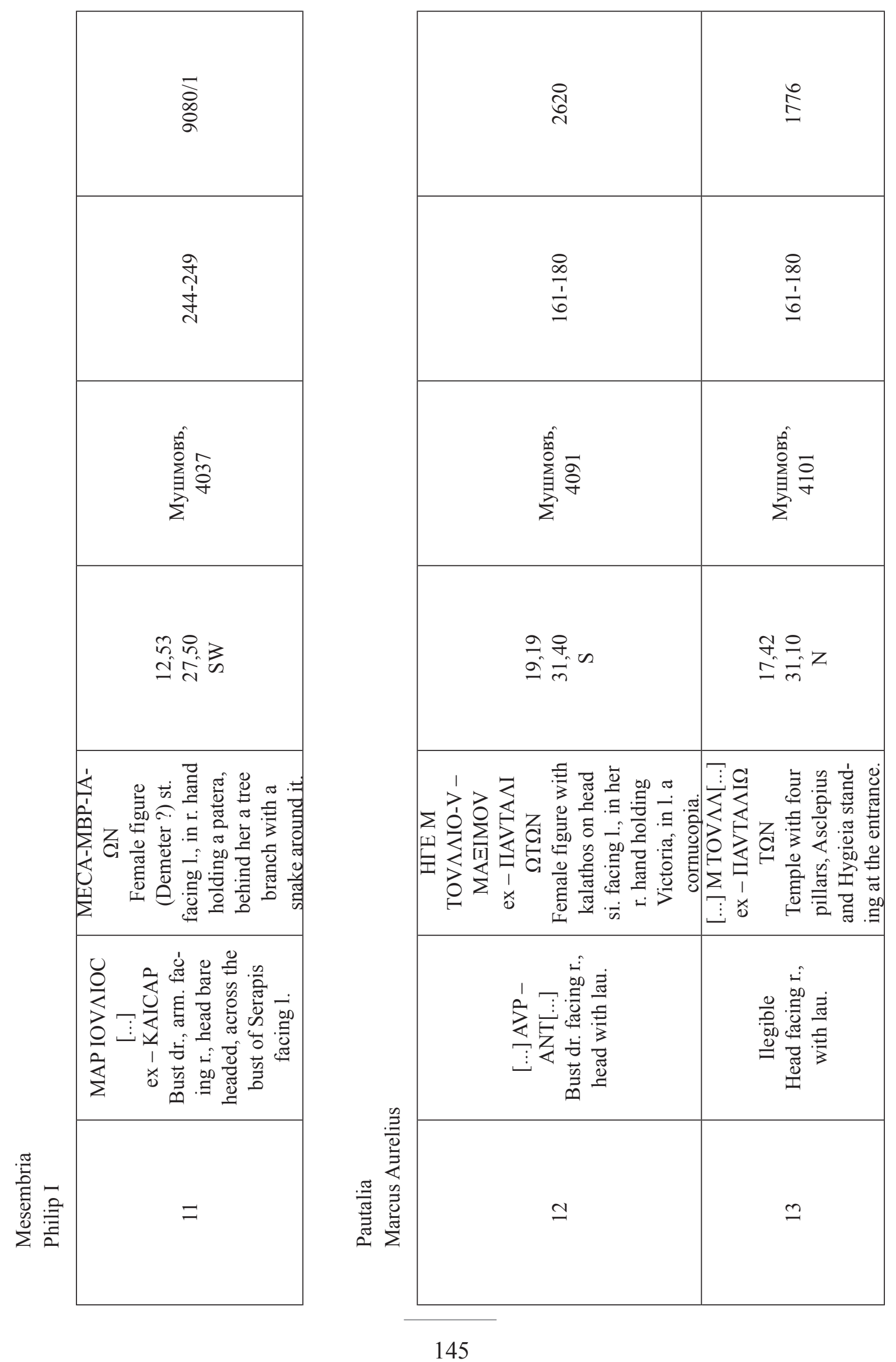


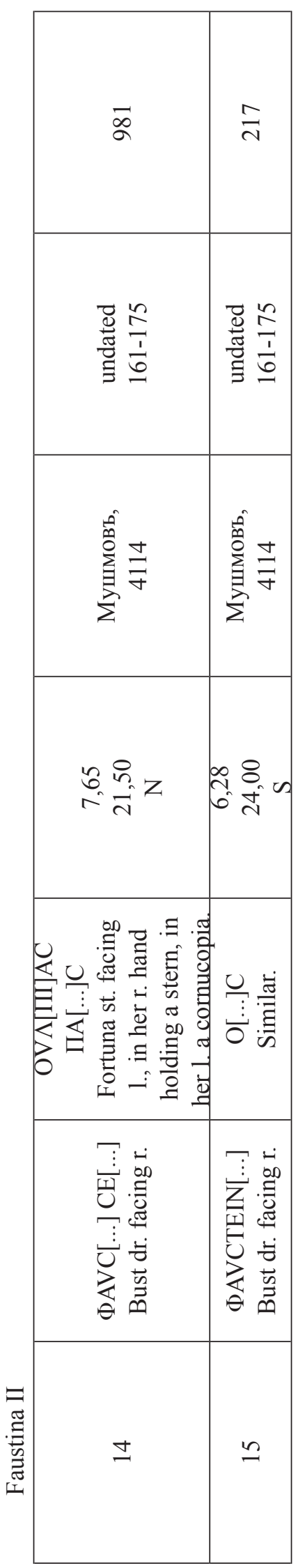

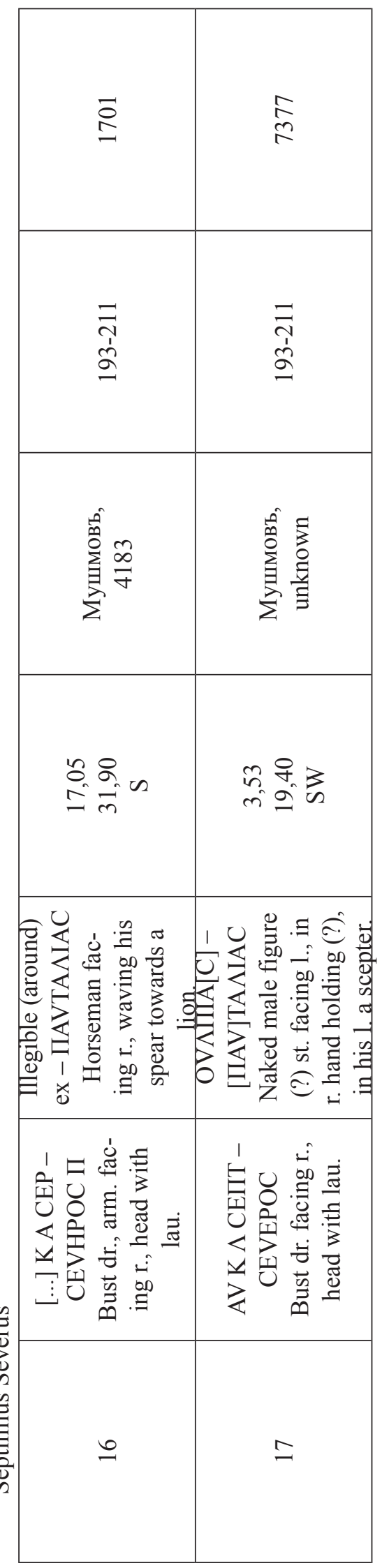



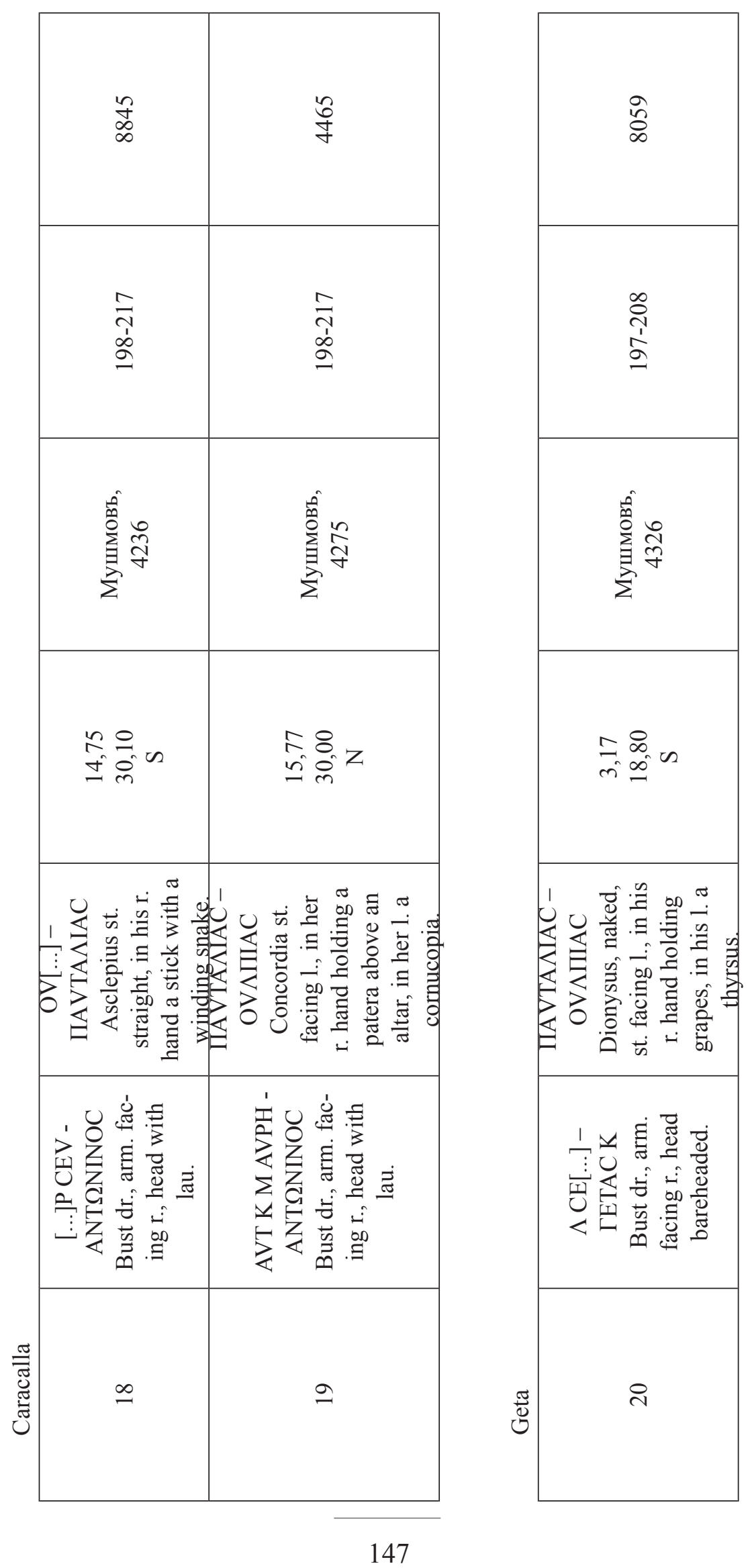

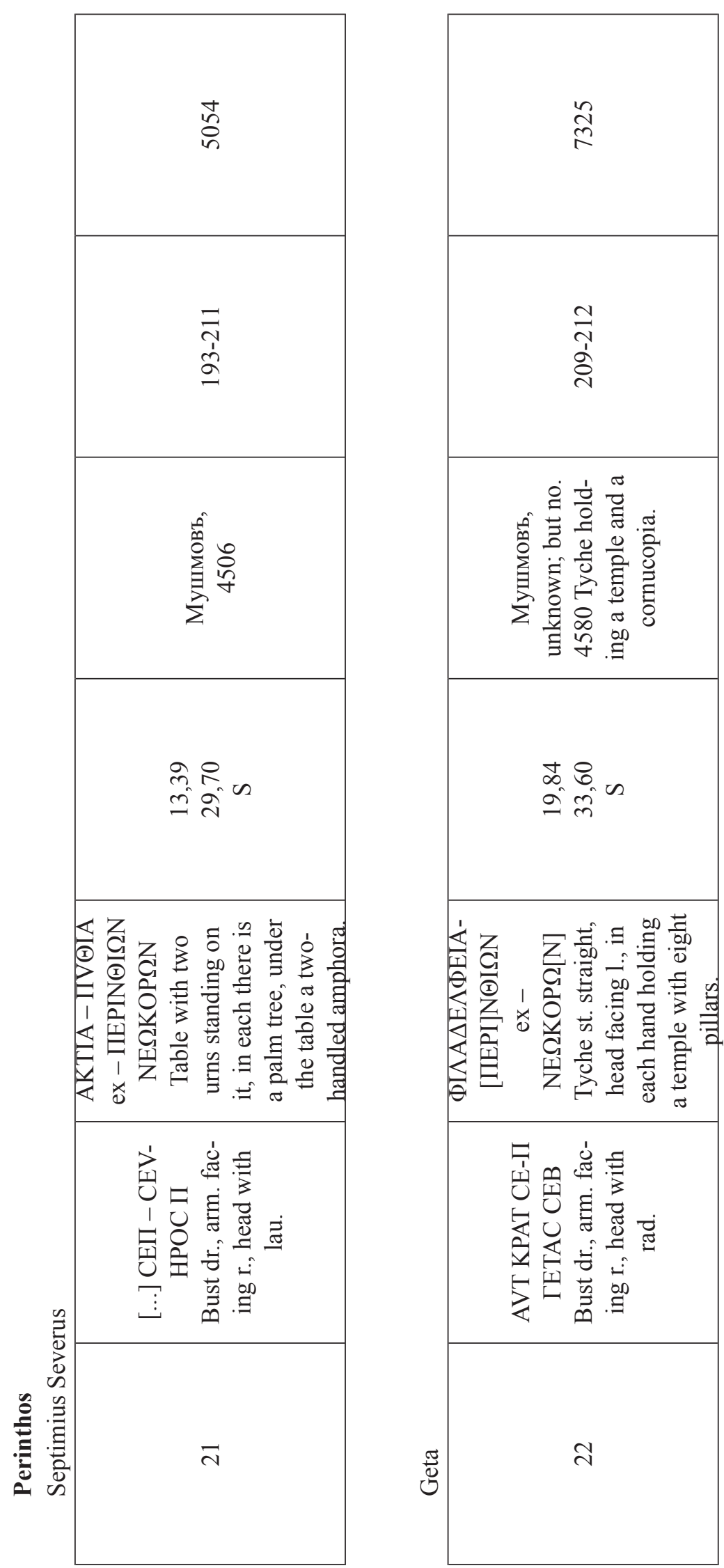

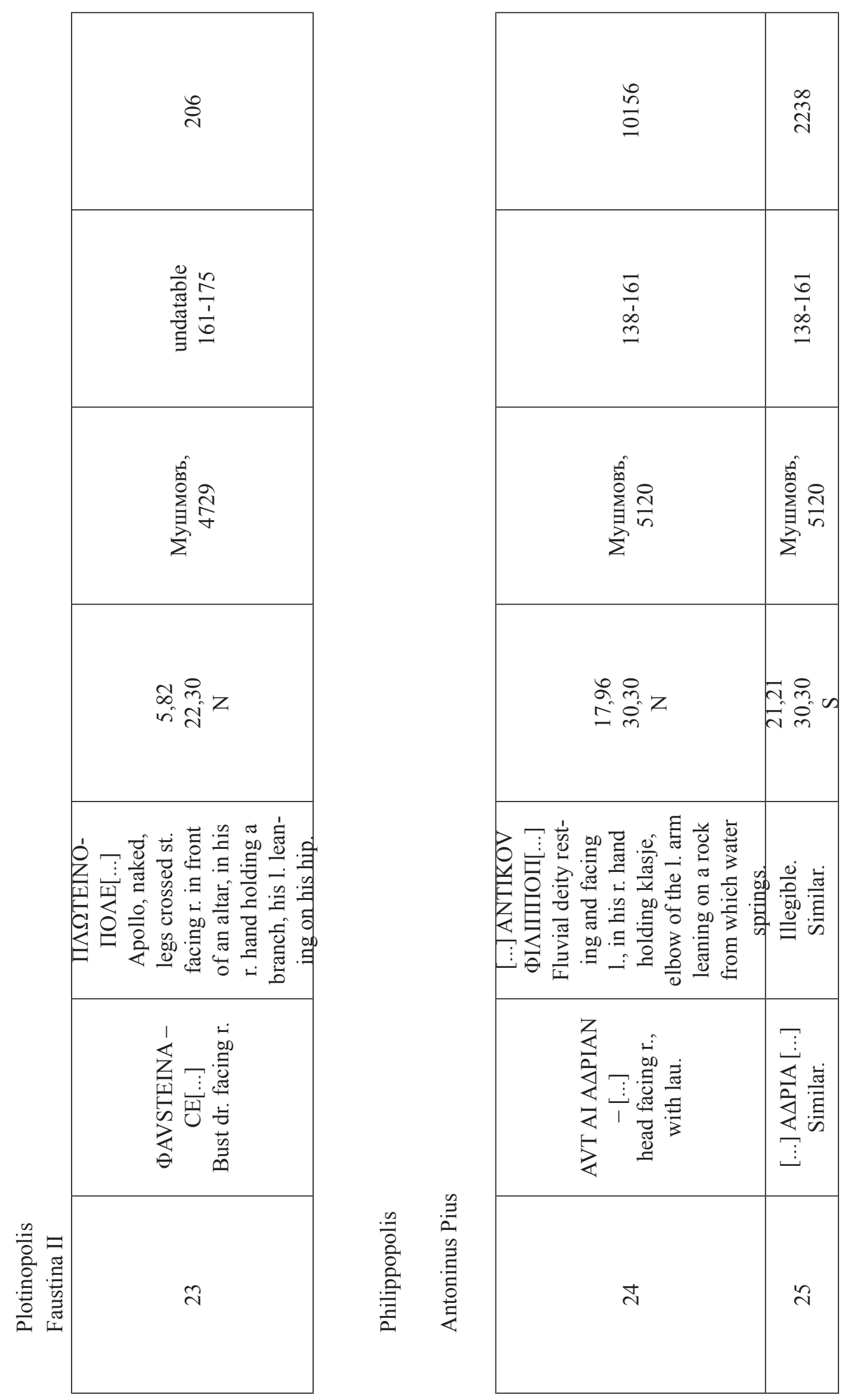


\section{BIBLIOGRAPHY}

Borić-Brešković, B. 1976

Novac kolonije Viminacijuma u zbirci Svetozara

St. Dušanića, Beograd: Muzej grada Beograda.

\section{Kos, P. 1986}

The Monetary Circulation in The Southeastern Alpine Region, ca. 300 BC-AD 1000, Situla 24, Ljubljana: Narodni muzej Slovenije.

\section{Мушмовъ, Н. А. 1912}

Антични монети на Балкански полуостров, София: Печатница на Г. И. Гавазов.

\section{Юрукова, Й. 1987}

Монетосеченето на градовете в Долна Мизия и Тракия II-III в. Хадрианопол, София: Булгарска академия на науките.

\section{Vojvoda, M. 2011}

Reversne predstave sa vojnim oznakama kovnice Nikeje na osnovu uzorka sa viminacijumske nekropole Više Grobalja, Glasnik SAD 25 (2009): 243-256.

\section{REZIME \\ NOVAC IZ KOVNICA TRAKIJE I DONJE MEZIJE NA VIMINACIJUMSKOJ NEKROPOLI "VIŠE GROBALJA"}

\section{KLJUČNE REČI: RIMSKO PROVINCIJSKO KOVANJE, Trakija, Donja Mezija, Viminacium.}

Na viminacijumskoj nekropoli „Više Grobalja“ pronađeno je 25 primeraka bronzanog novca koji su emitovani u provincijskim kovnicama Trakije i Donje Mezije. Zastupljen je novac sedam tračkih i dve donjomezijske kovnice (Tabla 1), u rasponu od Antonina Pija do Filipa I (Tabela 2).

Analiza pojedinačnih nalaza novca, pored značaja za istraživanje cirkulacije u pojedinim delovima Carstva, pruža podatke i za bolje upoznavanje sa istorijskim okolnostima u provincijama. $\mathrm{Za}$ istraživače balkanskih rimskih provincija veoma je važno publikovanje, u što većoj meri, kako pojedinačnih, tako i skupnih numizmatičkih nalaza sa teritorije Mezije Superior, Mezije Inferior i Trakije. Cilj ovog rada je upravo da široj javnosti ukaže na puteve cirkulacije provincijskog kovanja između pomenutih rimskih provincija, $\mathrm{u}$ određenom periodu. 

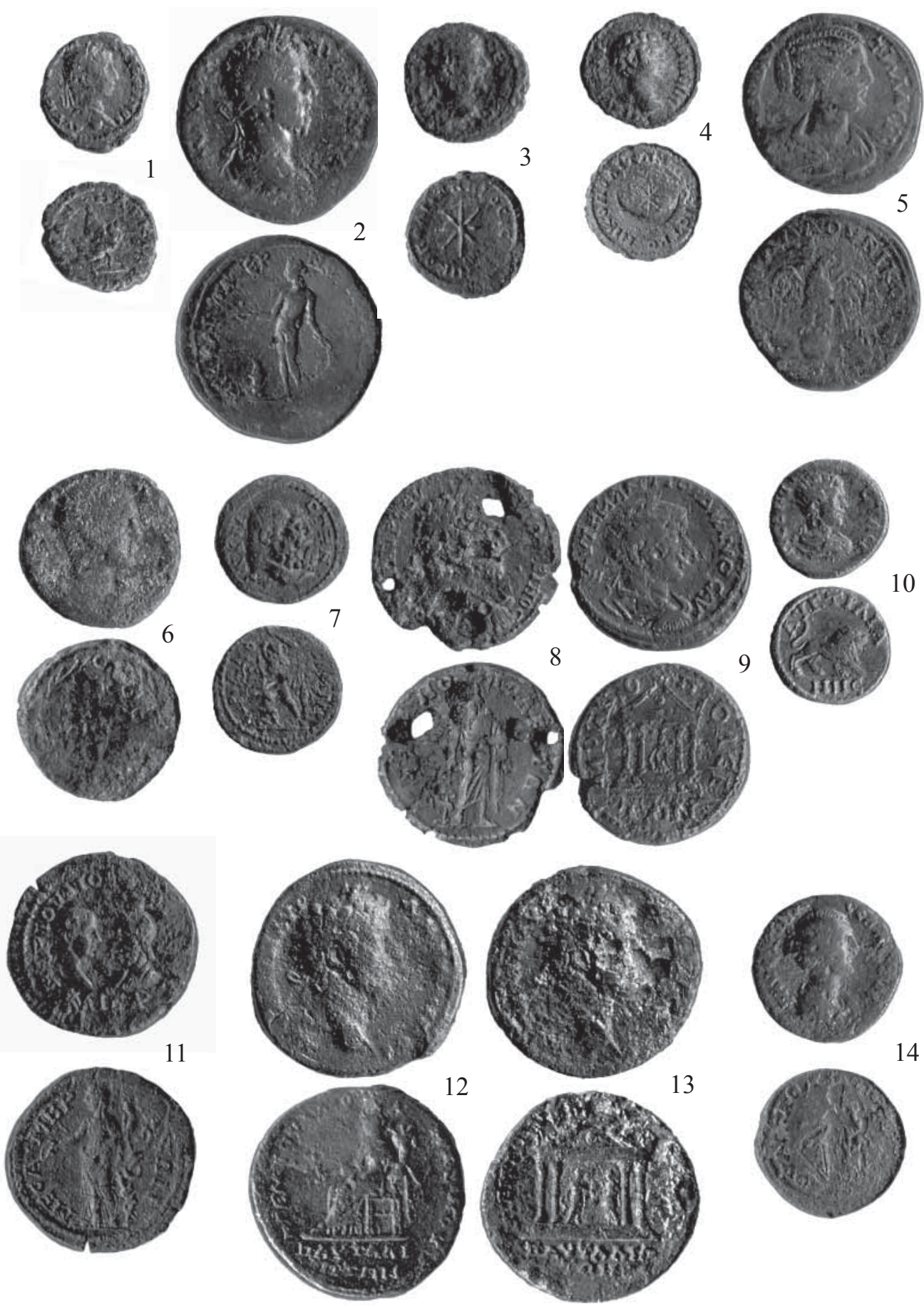

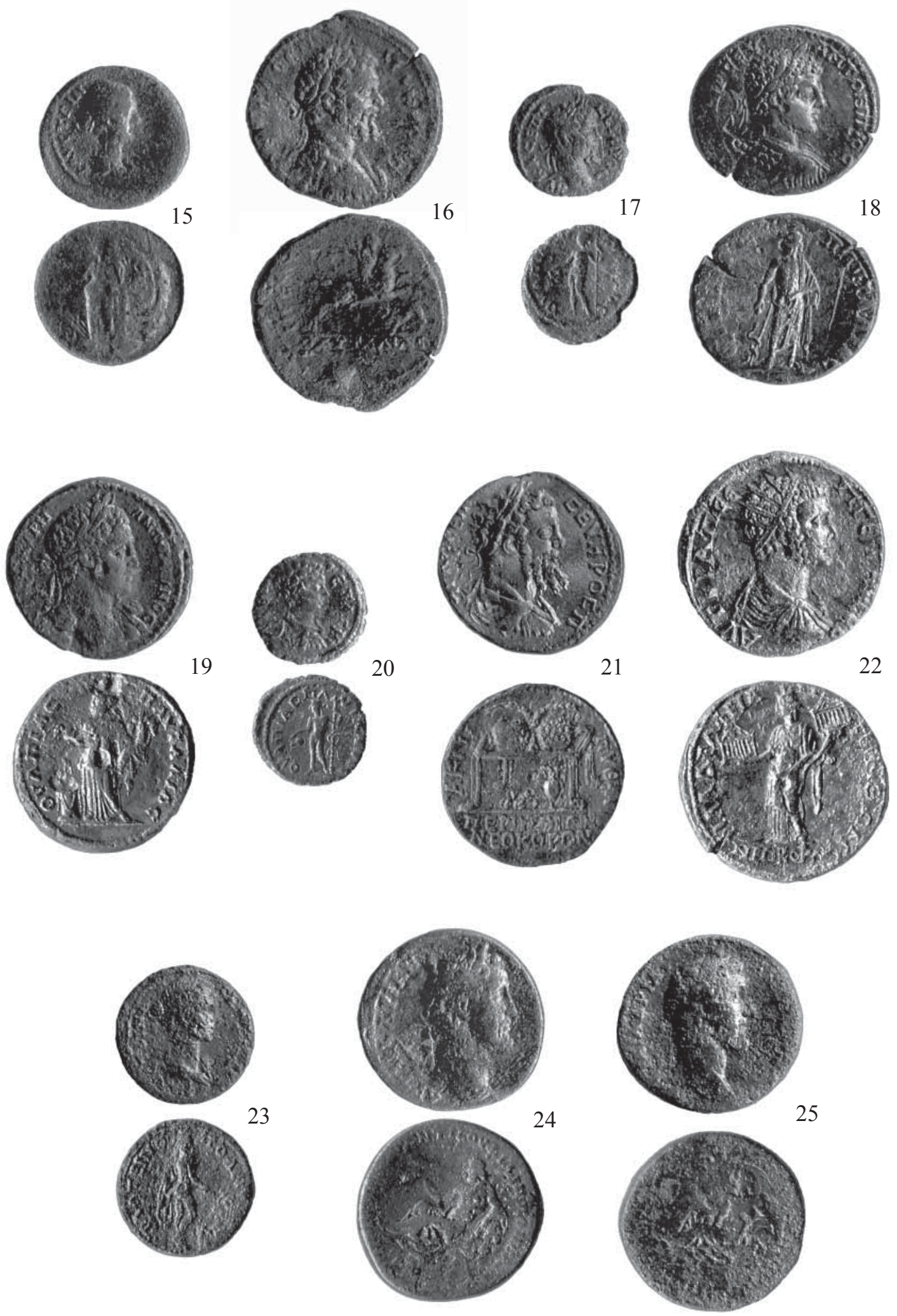